Original Research Paper

\title{
Pengembangan Budidaya Rumput Laut Kappaphycus alvarezii di Perairan Kecamatan Buer Kabupaten Sumbawa
}

\author{
Nunik Cokrowati ${ }^{1 *}$, Aluh Nikmatullah ${ }^{2}$, Zainal Abidin ${ }^{1}$, Edy Sulman ${ }^{3}$, Hardawiansyah ${ }^{3}$, \\ Erwansyah $^{4}$ \\ ${ }^{I}$ Program Studi Budidaya Perairan, Fakultas Pertanian, Universitas Mataram, Mataram, Lombok, NTB, \\ Indonesia. \\ ${ }^{2}$ Program Studi Agroekoteknologi, Fakultas Pertanian, Universitas Mataram, Mataram, Lombok, NTB, Indonesia. \\ ${ }^{3}$ Dinas Kelautan dan Perikanan Kabupaten Sumbawa Barat, Sumbawa Barat, NTB, Indonesia. \\ ${ }^{4}$ Program Studi Pertambangan, Universitas Cordova, Kabupaten Sumbawa Barat, NTB, Indonesia.
}

DOI: https://doi.org/10.29303/jpmpi.v4i2.800

Sitasi: Cokrowati, N., Nikmatullah, A., Sulman, E., Hardiawansyah., \& Erwansyah. (2021). Pengembangan Budidaya Rumput Laut Kappaphycus alvarezii di Perairan Kecamatan Buer Kabupaten Sumbawa. Jurnal Pengabdian Magister Pendidikan IPA, 4(2)

\section{Article history}

Received: 23 Maret 2021

Revised: 20 Mei 2021

Accepted: 18 Juni 2021

*Corresponding Author: Nunik Cokrowati, Program Studi Budidaya Perairan, Fakultas Pertanian Universitas Mataram, Mataram. Email: nunikcokrowati@unram.ac.id

\begin{abstract}
Budidaya rumput laut jenis Kappaphycus alvarezii dan Eucheuma spinosum telah di lakukan di perairan Indonesia yaitu di Lombok, Sumbawa, Nusa Tenggara Timur, Makasar, Situbondo, Prigi, Madura, Lampung dan Sorong Papua. Kappaphycus alvarezii merupakan jenis rumput laut penghasil kappa karaginan yang dapat digunakan sebagai bahan baku di industri makanan, farmasi dan kosmetik. Sedangkan Eucheuma spinosum merupakan rumput laut penghasil iota karaginan yang dapat dimanfaatkan untuk bahan baku di industri makanan. Tujuan kegiatan ini adalah mengembangkan budidaya rumput laut di perairan Kecamatan Buer Kabupaten Sumbawa Provinsi Nusa Tenggara Barat sesuai dengan karakteristik perairannya. Metode kegiatan yang digunakan adalah Focus Discussion Group (FGD) dan demplot budidaya rumput laut secara langsung di perairan laut. Hasil kegiatan ini adalah pada FGD dirumuskan permasalahan dan alternatif solusinya pada budidaya rumput laut. Kegiatan pengembangan budidaya rumput laut menggunakan metode patok dasar dilakukan di perairan Pulau Kaung. Budidaya menggunakan metode long line dikembangkan di perairan Labuan Mapin dan Labuan Burung. Pengembangan kegiatan budidaya tersebut diharapkan dapat meningkatkan ekonomi rumah tangga masyarakat. Kesimpulan dari kegiatan ini adalah upaya pengembangan budidaya rumput laut di perairan Kecamatan Buer telah dilakukan dengan metode budidaya disesuaikan dengan karakteristik masing-masing perairan perairan.
\end{abstract}

Kata kunci : Laut, alga, nelayan, karaginan, pendapatan, rumah tangga.

\section{Pendahuluan}

Budidaya rumput laut Kappaphicus alvarezii merupakan kegiatan budidaya yang dilakukan oleh masyarakat Sumbawa sejak tahun 1998. Budidaya rumput laut jenis Kappaphycus alvarezii juga di lakukan di perairan Indonesia lainnya yaitu di Makasar, Situbondo, Prigi, Madura, Lampung, Nusa Tenggara Timur dan Sorong Papua. Trono (1992) menjelaskan dalam analisa taksonominya bahwa Kappaphycus alvarezii merupakan jenis rumput laut penghasil kappa karaginan yang dapat digunakan sebagai bahan baku di industri makanan, farmasi dan kosmetik. Sedangkan Eucheuma spinosum merupakan rumput laut penghasil iota karaginan yang dapat dimanfaatkan untuk bahan baku di industri makanan. Ask et al., (2002) menjelaskan bahwa rumput laut jenis Kappaphycus daan Eucheuma merupakan sumber hidrokoloid 
karaginan yang bernilai ekonomis. Erlania et al., (2015) jenis rumput laut di perairan Sumbawa diantaranya adalah jenis alga merah, alga hijau dan alga coklat. Jenis tersebut hidup sesuai dengan habitat alaminya terutama sesuai dengan karakter subtrat dan perairan.

Kegiatan budidaya rumput laut mengalami pasang surut mengingat trend komoditas perikanan juga berubah-ubah setiap tahun. Pada tahun 2014 budidaya rumput laut mulai bangkit kembali di Sumbawa dan mulai dilakukan oleh nelayan sebagai alternatif kegiatan disaat mereka tidak dapat melaut mencari ikan akibat cuaca yang ekstrim. Demikian juga dengan yang dilakukan oleh nelayan di perairan Sumbawa, budidaya rumput laut bukan merupakan mata pencaharian utama. Budidaya rumput laut secara ekonomi dapat meningkatkan pendapatan rumah tangga nelayan. Fadli et al., (2017) menjelaskan hasil penelitiannya bahwa budidaya rumput laut dapat meningkatkan pendapatan dan ekonomi rumah tangga masyarakat Lombok Timur. Sehingga akan lebih baik jika budidaya rumput laut dilakukan secara kontinyu dan berkelanjutan untuk meningkatkan ekonomi rumah tangga. Pada tahun 2014, budidaya rumput laut di perairan wilayah Kecamatan Buer hanya dilakukan di desa Kaung. Perairan lain yang berpotensi dikembangkan adalah Labuhan Mapin dan Labuhan Burung. Pada perairan Labuhan Mapin, terdapat kegiatan budidaya rumput laut namun masih terbatas. Sedangkan di perairan Labuhan Burung belum ada kegiatan budidaya rumput laut. Sehingga perlu dilakukan pengembangan kegiatan budidaya rumput laut pada perairan tersebut. Tujuan kegiatan ini adalah mengembangkan budidaya rumput laut di perairan Kecamatan Buer Kabupaten Sumbawa Provinsi Nusa Tenggara Barat sesuai dengan karakteristik perairannya.

\section{Metode Kegiatan}

Kegiatan ini dilaksanakan di Kecamatan Buer Kabupaten Sumbawa Provinsi Nusa Tenggara Barat. Metode kegiatan yang digunakan adalah Focus Discussion Group (FGD) dan demplot budidaya rumput laut secara langsung di perairan laut. FGD dilakukan dengan tujuan untuk menggali permasalahan budidaya rumput laut selama ini di lokasi kegiatan dan mencari alternatif permasalahannya. Demplot budidaya rumput laut dilakukan oleh tim kegiatan bersama dengan pembudidaya dan masyarakat setempat.

\section{Hasil dan Pembahasan}

Kegiatan dilakasanakan dengan beberapa tahapan sebagaimana yang diuraikan di bawah ini. Kegiatan dilaksanakan secara bertahap dengan pendampingan yang berkelanjutan.

\section{Sosialisasi Kegiatan}

Sosialisasi kegiatan dilakukan kepada kelompok pembudidaya dan aparatur pemerintah desa Labuhan Mapin, Pulau Kaung dan Labuhan Burung. Sosialisasi kegiatan dilakukan dengan cara menjelaskan secara langsung hal-hal terkait program kegiatan yang akan dilakukan. Penjelasan tersebut dilakukan oleh tim pelaksana kegiatan ke aparatur pemerintah desa masing-masing serta usulan surat izin dan kegiatan. Sedangkan sosialisasi program dengan kelompok pembudidaya dilakukan pada saat pembentukan kelompok mitra. Program secara detail dijelaskan pada masingmasing kelompok dan dilakukan diskusi. Kegiatan yang disosialisasikan adalah budidaya sistem longline, disosialisasikan di kelompok Labuhan Mapin dan Labuhan Burung. Sedangkan budidaya sistem patok dasar, disosialisasikan di kelompok desa Pulau Kaung.

\section{Focus Discussion Group (FGD)}

FGD dilakukan antara tim kegiatan dengan anggota kelompok pembudidaya, stakeholder, pengusaha rumput laut dan industri pengolahan, pemuka masyarakat di Kantor Desa Kaung. Pada FGD dilakukan pemaparan program yang telah dilakukan, program yang akan dilakukan, permasalahan yang timbul pada budidaya rumput laut dan hal lain yg terkait dengan kegiatan ini. FGD ini dihadiri oleh perwakilan dari tim kegiatan dari Universitas Mataram, Bapeda Kabupaten Sumbawa, Dinas Kelautan dan Perikanan Kabupaten Sumbawa, Dinas Koperasi, Dinas Perindustrian dan Perdagangan, Badan Penyuluh Kabupaten Sumbawa, Penyuluh Perikanan Kecamatan Buer Kabupaten Sumbawa, aparat Pemerintah Kecamatan Buer, aparat Pemerintah Desa Pulau Kaung, pembudidaya dari desa Pulau Kaung, Labuhan Mapin dan Labuhan Burung. Berikut adalah gambar pada saat dilakukan FGD di kantor Kecamatan Buer. 


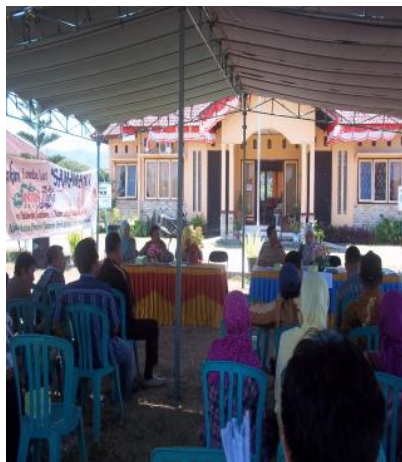

Gambar 1. Pelaksanaan

FGD optimalisasi

budidaya rumput laut

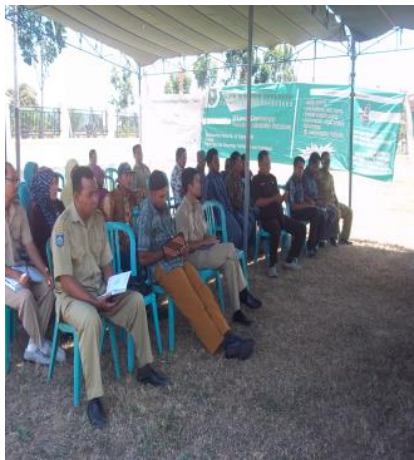

Gambar 2. Peserta FGD pengembangan budidaya rumput laut
Perwakilan stakeholder memberikan paparan singkat program yang terkait dengan rumput laut. Pada FGD ini didiskusikan permasalahan yang terjadi di masyarakat terkait dengan budidaya rumput laut dan bagaimana alternatif solusinya. Hasil dari FGD adalah :

1.Budidaya rumput laut merupakan usaha yang signifikan dapat meningkatkan pendapatan dan ekonomi keluarga.

2.Pembudidaya membutuhkan pendampingan yang berlanjut dari pemerintah dan akademisi.

3.Pemasaran harus dikontrol oleh pemerintah sehingga tidak terjadi monopoli pembeli dan monopoli harga.

4. Tidak boleh ada retribusi atas pemanfaatan perairan untuk budidaya rumput laut dan komoditas perikanan lainnya.

5.Bantuan sarana, prasarana, bibit rumput laut untuk pembudidaya hendaknya disertai dengan pendampingan teknis oleh penyuluh pembudidaya.

6.Dibutuhkan komitmen bersama antar semua stakeholder untuk menjaga kelestarian dan keberlanjutan sumberdaya perikanan di perairan kecamatan Buer.

\section{Pengembangan budidaya Sistem Lepas Dasar di Desa Pulau Kaung}

Pengembangan budidaya sistem lepas dasar atau sistem patok dasar di lakukan di desa Pulau Kaung. Pengembangan sistem lepas dasar dilakukan mengingat potensi daerah pasang surut perairan Pulau Kaung memungkinkan dilakukan sistem tersebut. Selama ini potensi daerah pasang surut masih belum dimanfaatkan untuk kegiatan budidaya. Introduksi sistem lepas dasar dilakukan dengan cara demplot 1 unit sistem lepas dasar dengan ukuran $50 \mathrm{~m}$ x $30 \mathrm{~m}$. Jenis yang ditanam adalah Kappaphycus alvarezii strain coklat dan Kappaphycus alvarezii strain hijau, masing-masing 25 ris per jenis rumput laut. Badan Standar Nasional, (2011) menetapkan standar bahwa metode patok dasar (off bottom) adalah metode budidaya rumput laut di atas dasar perairan, namun pada saat surut terendah masih terendam air 20-50 $\mathrm{cm}$. Budidaya dilakukan dengan menggunakan tali ris utama yang diikatkan pada patok yang dipasang secara teratur. Patok yang digunakan dapat dari bahan kayu, bambu, atau besi yang berfungsi sebagai pancang untuk mengikatkan tali ris utama. Supiandi et al., (2020) melakukan budidaya Kappaphycus alvarezii menggunakan metode patok dasar dengan capiaan rendemen karaginan maksimal sebesar $17 \%$.

Pengikatan rumput laut dilakukan didaratan dan dilakukan oleh anggota keluarga pembudidaya sehingga biaya produksi dapat diminimalkan. Berikut gambar kegiatan pengikatan rumput laut di daratan yang selanjutnya dibawa ke laut untuk diikatkan di tali ris.

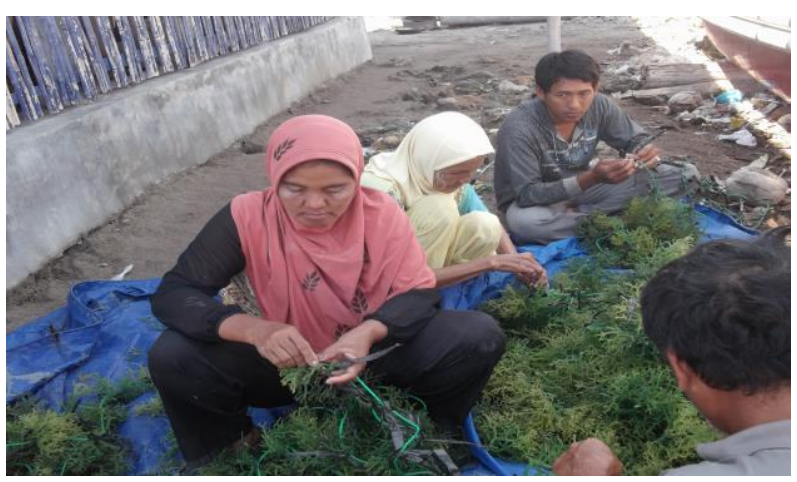

Gambar 3. Kegiatan pengikatan rumput laut pada tali ris.

\section{Pengembangan Budidaya Sistem Long-Line di Labuan Mapin}

Pembudidaya di desa Labuhan Mapin selama ini kontinyu melakukan budidaya rumput laut dengan metode longline. Namun masih belum dilakukan secara optimal, dikarenakan keterbatasan bibit, ketidak sesuaian jenis dengan ekologi perairan dan rendahnya minat masyarakat terhadap budidaya rumput laut. Berikut adalah rumput laut yang dibudidayakan di Labuhan Mapin. 


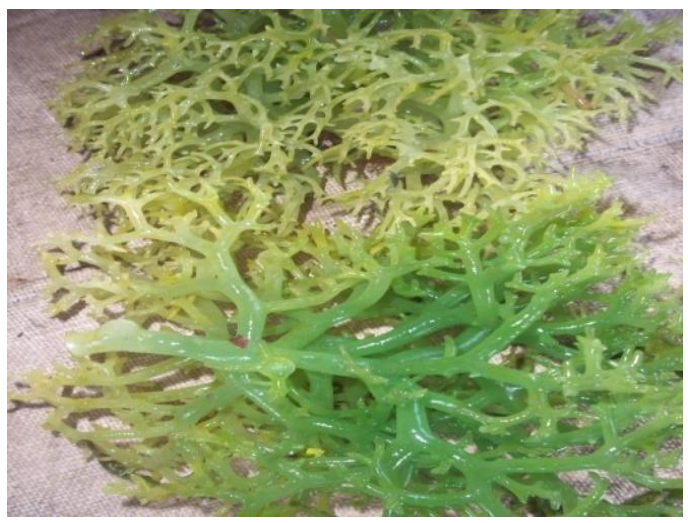

Gambar 3. Kappaphycus alvarezii strain hijau

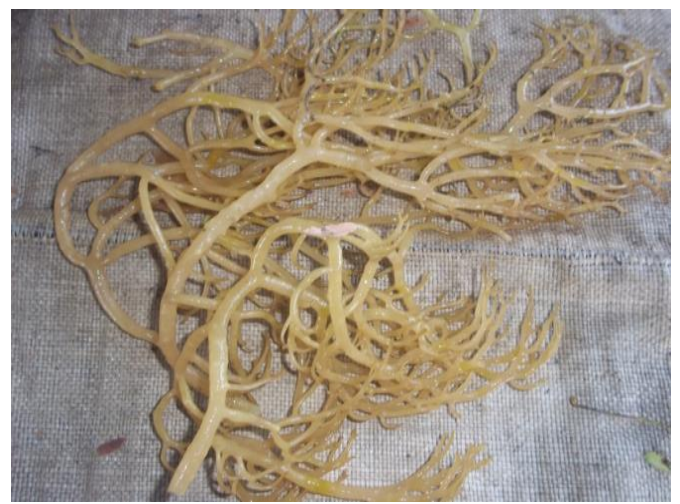

Gambar 4 . Kappaphycus alvarezii strain coklat

Metode longline merupakan metode budidaya yang dilakukan pada perairan yang memiliki kedalaman lebih dari 5 meter dan meiliki gerakan air yang kuat. Longline di buat dari tali ris utama yang diikat dengan jangkar di dasar perairan. Abdillah (2019) menjelaskan bahwa metode longline dilakukan dengan cara membudidayakan rumput laut di kolom permukaan perairan dengan menggunakan tali yang dibentangkan. Tali ris dibentangkan dari titik satu ke titik yang lain, dalam bentuk jalur lepas atau terangkai dengan bantuan pelampung dan diikatkan pada jangkar.

Budidaya rumput laut di Labuhan Mapin dilakukan oleh pembudidaya yang datang dari sekitar Labuhan Mapin. Pembudidaya tinggal pada rumah-rumah sementara selama melakukan kegiatan budidaya. Hal ini juga yang menyebabkan budidaya tidak dapat dilakukan secara optimal. Berikut kegiatan pembudidaya rumput laut yang ada di Labuhan Mapin.

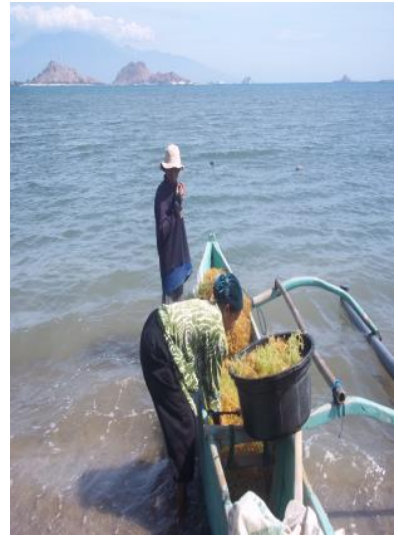

Gambar 5. Persiapan pengikatan bibit ke laut

\section{Introduksi budidaya rumput laut Sistem Long-line di Labuhan Burung}

Introduksi budidaya sistem longline akan dilakukan dengan pembuatan demplot longline ukuran $20 \mathrm{~m}$ x $10 \mathrm{~m}$. jenis yang ditanam adalah Kappaphycus alvarezii. Dari demplot tersebut diharapkan diketahui jenis rumput laut yang sesuai untuk dibudidayakan di perairan Labuhan Burung dan dapat menimbulkan minat masyarakat pada kegiatan budidaya rumput laut. Labuhan burung diharapkan dapat menjadi produsen bibit rumput laut. Berikut adalah gambar Kappaphycus alvarezii yang dibudidayakan menggunakan metode longline.

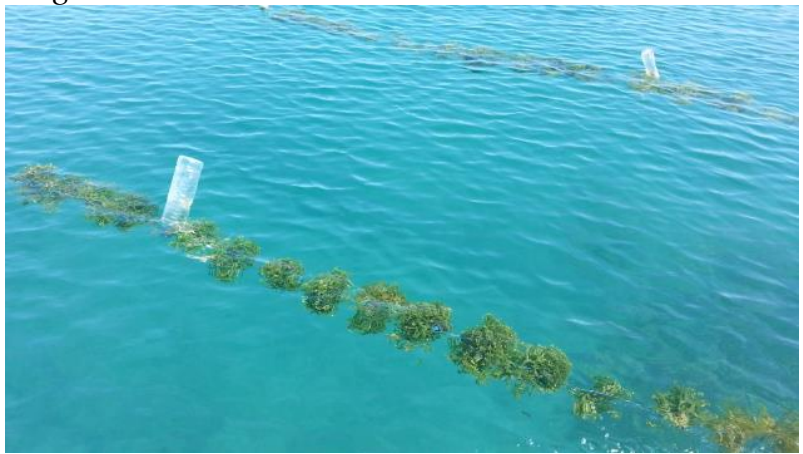

Gambar 7. Kappaphucus alvarezii pada metode longline.

Metode longline memerlukan biaya produksi lebih banyak dibanding dengan metode patok dasar. Biaya pembelian bahan untuk konstruksi longline tergantung dari kedalaman perairan dan luasan longline. Semakin dalam perairan maka tali jangkar yang dibutuhkan juga semakin banyak dan jangkar juga harus jangkar yang kuat. Biaya produksi pada metode ini lebih tinggi juga karena pada kegiatan pengontrolan diperlukan perahu dan bahan bakar 
karena posisi longline tidak dapat dijangkau dengan jalan kaki sebagaimana pada posisi metode patok dasar.

\section{Kesimpulan}

Kesimpulan dari kegiatan ini adalah upaya pengembangan budidaya rumput laut di perairan Kecamatan Buer telah dilakukan dengan metode budidaya disesuaikan dengan karakteristik masingmasing perairan. Budidaya rumput laut dengan menggunakan patok dasar telah dikembangkan di perairan Pulau Kaung. Budidaya rumput laut menggunakan metode longline telah dikembangkan di perairan Labuhan Mapin dan Labuhan Burung.

\section{Saran}

Kegiatan pendampingan kegiatan budidaya rumput laut sebaiknya terus menerus dilakukan dan akan terlihat hasilnya minimal tiga tahun setelah dilaksanakannya kegiatan pada tahun pertama.

\section{Daftar Pustaka}

Ask, EI and Azanza, R.V. 2002. Advances in Cultivation Technology of Commercial Eucheumatoid Species: a Review With Suggestions for Future Research. Aquaculture. $206 \quad$ (3/4) :257-277. https://www.academia.edu/27550479/

Abdillah, S. R. dan A. A. 2019. Studi Pertumbuhan Bibit Rumput Laut (Kappaphycus alvarezii) Hasil Kultur Jaringan Dengan Metode Longline Berbingkai di Balai Besar Perikanan Budidaya Laut Lampung. Jurnal Perikanan Pantura. 2(1).
DOI: http://dx.doi.org/10.30587/jpp.v2i1.805

Badan Standar Nasional (BSN). 2011. Produksi Bibit Rumput Laut Kotoni (Eucheuma cottonii) - Bagian 1: Metode Lepas Dasar. Jakarta. http://kkp.go.id/

Erlania dan I Nyoman, R. 2015. Distribusi Rumput Laut Alam Berdasarkan Karakteristik Dasar Perairan Di Kawasan Rataan Terumbu di Labuhanbua. Nusa Tenggara Barat: Strategi Pengelolaan Untuk Pengembangan Budidaya. Jurnal Riset Akuakultur. Volume 10 Nomor 3.

DOI: http://dx.doi.org/10.15578/jra.10.3.201 5.449-457

Fadli, Rachmat, P. dan Harianto. 2017. Analisis Daya Saing Agribisnis Rumput Laut. Di Kabupaten Lombok Timur. Jurnal Agribisnis Indonesia. Vol 5 No. 2. Halaman: 111-124. ISSN 2354-5690; E-ISSN 2579-3594. https://jurnal.ipb.ac.id.

Supiandi, M., Nunik, C., Ibadur, R. 2020. Pengaruh Perbedaan Jarak Tanam Terhadap Pertumbuhan Rumput Laut (Eucheuma cottonii) Hasil Kultur Jaringan Dengan Metode Patok Dasar Di Periran Gerupuk. Jurnal Perikanan. Volume 10. No. 2 : 158166.

DOI https://doi.org/10.29303/jp.v10i2.206

Trono, G.C. 1992. Eucheuma and Kappaphycus : Taxonomy and Cultivation. Bull. Mar. Sci. Fish. Kochi University. No. 12. pp.51-65. https://www.doc-developpement-durable.org. 